\title{
Review
}

\section{Biodiversity in grassland}

\section{Josef Nösberger*, Martin Messerli, Christoph Carlen}

\author{
Institute of Plant Sciences, Swiss Federal Institute of Technology, 8092 Zurich, Switzerland
}

(Received 22 August 1998; accepted 24 September 1998)

\begin{abstract}
The aim of this paper is to review the role of biodiversity and the underlying mechanisms in managed grassland and to present new results. Modern farming methods have been criticised for their negative effect on species-richness and their impact on environment and landscape. There is an increasing wide-spread desire to promote biodiversity and attractive landscapes as well as to retain rural communities. Conservation of biodiversity is primarily a regional goal, not a goal of individual farmers. Grassland management to favour biodiversity will require compromise. Agricultural management influences sward structure vertically and horizontally over space and time. Insights into these relationships are important to understand the mechanisms responsible for changes in the floristic composition and the productivity of grassland. Two case-studies with Trifolium repens L. (white clover) and Festuca pratensis Huds. (meadow fescue) are summarised to identify driving forces for the changes of the yield contribution of selected species in grassland. Canopy structure and growth form of white clover determine the foraging for light, and the weak competitive ability of meadow fescue is caused by a smaller proportion of leal area in the upper layers of the canopy in interspecific shoot competition. Long-term experiments show that management also influences surprisingly rapid microevolution within individual species. It is concluded that management for habitat heterogeneity at all scales will conserve most of the biotic diversity of a site. (C) Elsevier/Inra
\end{abstract}

\section{biodiversity / grassland management / white clover / meadow fescue / microevolution}

Résumé - Biodiversité des prairies. L'objectif de cet article est d'analyser le rôle de la biodiversité et les mécanismes fondamentaux dans la gestion de prairies ; sont également présentés de nouveaux résultats dans ce domaine et les effets négatifs des méthodes agricoles modernes sur la richesse des espèces végétales, leur impact sur l'environnement et le paysage. Il y a un fort désir de promouvoir la biodiversité, de rendre des paysages attractifs ainsi que de maintenir les communautés rurales. La préservation de la biodiversité est surtout une volonté régionale et non celle d'exploitants. La gestion de prairies pour atteindre cet objectif exigera donc des compromis. En effet, la conduite agricole influe sur la structure verticale et horizontale du couvert végétal à l'échelle spatiale et temporelle. L'évaluation de ces effets à divers niveaux est importante pour comprendre les mécanismes responsables des changements intervenant dans la composition botanique et la productivité des prairies. Deux études de cas : l'une avec Trifolium répens L. (trèfle blanc), l'autre avec Festuca pratensis

\footnotetext{
* Correspondence and reprints

Tel.: (41) I 6323 881; fax: (41) I 6321 153; e-mail: josef.noesberger@ipw.agrl.ethz.ch
} 
Huds (fétuque des près), sont présentées afin d'identifier les processus impliqués dans le changement de rendement des espèces. La structure du couvert végétal et la forme de croissance du trèfle blanc déterminent sa recherche de lumière. La faible aptitude de compétitivité de la fétuque des prés est due à une densité insuffisante de la surface foliaire dans la couche supérieure du couvert. Des expériences à long terme montrent que la conduite agricole provoque aussi des microévolutions rapides pour différentes espèces. En conclusion, la gestion pour l'hétérogénéité de l'habitat à toutes les échelles conservera la majeure partie de la diversité biotique d'un site. $\odot$ Elsevier/Inra

biodiversité / gestion prairiale / trèfle blanc / fétuque des prés / microévolution

\section{INTRODUCTION}

Since the fifties, animal production in most European countries has increased considerably, and the economic efficiency of milk and meat production has improved. Higher milk production per cow required the purchase of more concentrates which contributed to plant nutrient input of farms. The demand for a more digestible forage had the consequence of grassland being defoliated earlier in spring and more frequently. N-fertilisation had to be augmented. In mild and humid valley regions of central and northern Switzerland a type of permanent meadow developed, in which Italian ryegrass (Lolium multiflorum) dominates [1]. More intensive grassland management brought with $\mathrm{N}$-fertilisation an increase in economic efficiency and led to a reduction in the number of plant and animal species. Modern farming methods have been criticised for their impact on the environment and the landscape. Grassland management is now faced with a choice between the opportunities offered by modern technologies and the demand for high biodiversity and attractive landscapes. There is an European-wide move towards extensive systems of management as a result of the reform of agricultural policy and a desire to promote biodiversity and retain rural communities. That is especially true in regions where semi-natural grassland dominates the landscape and where it has the potential to sustain or increase biodiversity. However, it is not only modern farming practices that can negati- vely affect biodiversity in grassland. There is an increasing number of reports of negative effects of air pollution on biodiversity. Today, nitrogen loads and levels of tropospheric ozone are the predominant forms of air pollution affecting species diversity of the flora [6]. Results of recent investigations at the Institute of Environmental Protection and Agriculture, Bern- Liebefeld, indicate that the loss of floristic diversity in permanent grassland is possible because of the high relative sensitivity to ozone of some typical species.

From the agricultural perspective, biodiversity of grassland is not a primary goal $[18,19]$. Species-richness is usually associated with lower productivity and poor forage quality, as was shown by Thomet [27]. Very colourful associations (e.g. Mesobromion) tend to attract the attention of conservationists. However, the quality of the hay is characterised by high levels of fibre and low contents of protein and phosphorus [4]; the intake requirements of very productive animals cannot be met. The very low nutritive value therefore limits the suitability of hay from extensively managed meadows in ruminant rations. However, low quality forage has its uses. Experiments conducted at the Swiss Federal Research Station for Animal Production led to the conclusion that, on an average Swiss farm, the quality of 10 to 15 per cent of the roughage does not need to be higher than that of hay from extensively managed meadows [10]. Cows in the first four to six weeks of 
their dry period and heifers of 250 to $450 \mathrm{~kg}$ weight can be fed with such a hay.

The aim of grassland science is to analyse the influence of vegetation history, sitespecific conditions and farming practices on quality and quantity of sward growth, to investigate the economic efficency of the agricultural use of grassland, and to answer the question, how grassland management can help to maintain or increase biodiversity or to favour specific species.

\section{CHARACTERISTICS OF BIODIVERSITY}

Biodiversity is an all-embracing term, referring to the diversity of life. It is generally defined as the variety of living organisms, the genetic differences among them, and the diversity of communities, ecosystems and landscapes in which they occur. The culture and knowledge of the indigenous population can also be considered to be a part of total biodiversity; numerous interactions occur among the various components of the system. Biodiversity is, therefore, not just one phenomenon, it is what Peters [20] calls a concept cluster. Viewing biodiversity from different perspectives leads to different ways of perceiving what is involved and what is important.

According to the definition of biodiversity, variety of life is expressed in multiple ways. We can distinguish between different key elements, that can be divided into three groups: genetic diversity, organismal diversity and ecological diversity. These groups are intimately linked, and, in some cases, share common elements, e.g. populations [8]. The adaptive strategies of individual species when competing for resources, and their tolerance to environmental stress and to partial destruction become significant for demographic processes. All of these processes react differently to changes in the environment and farming practices. Intensive management of semi-natural grassland may lead to a type of vegetation which is dominated by a few wide-spread species, e.g. Italian ryegrass in mild and humid regions. In crop rotations with a ley -farming system, grass-clover seed mixtures with a complement of wild flowers can be used to establish swards which meet agricultural and ecological requirements [11]. The abandonment of grasslands that are not easily managed with large machines can also be negative for diversity. Ungrazed patches are often short-lived, the invasion by shrubs can eventually lead to a permanent forested vegetation cover and, thus, to less diversity.

There is apparently a shift in the agricultural economy towards the abandonment of farmland. The fear that this will lead to spontaneous succession and to open field species is as widespread as the hope that this trend may provide larger habitats for forest species. An agricultural landscape is not only a set of patches and corridors exhibiting particular patterns in space and time; it also includes the space where different farms and, hence, different farming systems interact [2]. It is necessary to develop systems of management that consider diversity not only as species richness on a small scale of cutting and fertilisation regimes but on the larger scale of landscape structure. On a large spatial scale, when processes in the landscape are important, biodiversity can be expressed in life forms and in mosaic diversity. Fewer regional landscapes results in less local species diversity. Therefore, conservation of biodiversity is primarily a regional goal, not a goal just of individual farmers. However, it cannot be achieved without farmers who are integrating in situ conservation with sustainable grassland management. On a smaller scale, biodiversity is reflected in the identity, abundance, distribution and dominance of species. As a general rule, the greater the variety of plant species in the vegetation, the greater the diversity of the associated animals [17]. Efforts made by agriculture to support biodiversity have concentrated on plant com- 
munities rather than on key species of flora and fauna (i.e., rare and endangered species). It would be a challenge for grassland farming to develop management systems which are supportive of key species.

Why has biodiversity become such a hotly debated topic? Various major forces are involved: accelerated species extinction, negative effects of many farming practices on the environment (e.g., pollution or soil erosion) and changing social values. The most important reason to be concerned about biodiversity is because it is a moral obligation. Many people believe that human beings are morally obliged to protect fellow creatures, regardless of whether they are intrinsically valuable or not. The conservation of biodiversity for future generations is at the core of the sustainability issue [30]. The second major reason why biodiversity is important involves aesthetics and amenities. The third reason for promoting biodiversity, its importance in relation to food, fuel, building material and industrial products is widely accepted by the scientific community. Extinction is still regarded as a final, irreversible loss of options. The fourth, least understood but most important value of biodiversity is the array of 'services' provided by ecosystems as a life-support system. Essential ecosystem services include maintenance of the gaseous composition of the atmosphere, amelioration of climate, sequestration of carbon into the soil, cycling of nutrients, and natural control of pathogenic and parasitic organisms. Loss of biodiversity is assumed to negatively influence the genetic resources as well as the quality and quantity of ecosystem services, all of which ultimately lead to unfavourable economic consequences.

\section{PRODUCTIVITY AND DIVERSITY}

Floristic composition and the potential productivity of grassland is a quintessential ecological and demographic phenomenon, representing the net result of a complex set of interacting physiological, ecological, evolutionary, demographic and physical processes.

In most situations, an increase in plant productivity due to fertilisation leads to a decrease in the number of plant species that coexist in a given area. It is commonly recognised that soil fertility factors have a profound effect on the floristic composition of grasslands, especially in acidic, calcareous and saline habitats. As a result of applying fertilisers, semi-natural grasslands have gradually been transformed into intensively managed grasslands. The numerous slowgrowing species, typical of low fertility sites, are gradually being replaced by a few species with a high growth rate and a high nutrient demand, resulting in a decrease in species diversity. Globally one of the oldest 'biodiversity' grassland experiments (Park Grass Experiment at the Rothamsted Experimental Station in Great Britain), that began in 1856 and is still in progress, has continued to provide insights into issues related to evolution, population, community and ecosystem ecology. The long-term data have become increasingly powerful. In these experiments, various fertiliser and liming treatments were evaluated for their effect on yield. An early result that became stronger over time was a decrease in the number of species that occurred in the plots with the highest yield [25]. Recent observations in 98 permanent pastures on dairy farms on the Lorraine plateau also showed that the number of species and the Shannon Index (calculated on the basis of species frequency) were reduced by increasing rates of mineral fertilisers and by increasing frequency of cutting or grazing [22]. Species number was affected particularly by nutrient status of the soil and the Shannon Index by the duration of the growth period.

High species-diversity is usually associated with a relatively low herbage yield. The highest species-diversity is found in grasslands with a standing biomass of be- 
tween 400 and $600 \mathrm{~g} \mathrm{DM} \mathrm{m}^{-2}[5,29]$. However, the effect of productivity on species richness may also depend on soil $\mathrm{pH}$ [28]. At a given level of productivity in the Park Grass Experiment at Rothamsted, more acidic plots had fewer species. The experimentally demonstrated inverse relationship between productivity and species richness stands in contrast to the commonly reported pattern for habitats along latitudinal productivity gradients [21]. For many grassland communities in environmentally sensitive areas maximum diversity will be obtained by a combination of grazing management, fertiliser application and cutting regime [16]. Invertebrate and mammal species diversity is likely to be maximised at low grazing pressures and low levels of fertiliser application.

The mechanism generally considered to be responsible for this decrease in diversity of plant species is an increased competition at higher levels of productivity, although it is not always easy to separate the effects of competition from the effects of specific growth characteristics of the competing species and/or the environment. To achieve a better understanding of the processes that determine floristic composition and, hence, the yield and quality potential of semi-natural grassland, it is necessary to analyse the mostly mutually negative interactions between species. Competition for resources in the shoot and root zone is such a mutually negative interaction and arises because individuals of different species more or less efficiently consume the same resources. In addition, the little-known interactions between vegetative growth and the propagation of plants contribute to the difficulties in understanding the response of one plant species to the effects of the environment and management in the field as compared to that of its neighbours. In semi-natural grassland, recruitment limitation may also control species abundance. In intensively managed grassland that is dominated by Italian ryegrass, seed production is the major limiting factor of the life history. The recruitment of meadow fescue is also partially dependent on seed shedding [32, 33].

A particular problem associated with biodiversity grassland experiments is that the primary experimental treatment for influencing the productivity of certain species is often correlated with variation of other biological or soil fertility factors; this can have a stronger effect on the experimental response than the putative primary treatment. These 'hidden treatments' can produce strong biological responses that may be misinterpreted as being a consequence of a particular level of species diversity [9]. Current interest in the biodiversity of managed grassland requires experimental approaches that are able to distinguish between the direct and indirect effects of the ecosystem, including management, on processes that govern biodiversity from the effect of biodiversity on ecosystem processes. To understand this complexity, it is our intention to focus on a few processes so as to develop a solid basis for understanding patterns of changes in managed grassland. Experiments at the plant and community levels, under controlled conditions and in the field, are prerequisites for gaining insight into the underlying mechanisms. In addition, we also have to consider unpredictable or stochastic processes such as climatic fluctuations, disturbances, and the vagaries of dispersal.

\section{MANAGEMENT OF SEMI- NATURAL GRASSLAND TO FAVOUR DESIRED SPECIES: TWO CASE STUDIES}

\subsection{Yield proportion of white clover as affected by nitrogen fertilisation and cutting frequency}

In a traditionally extensively managed semi-natural meadow (48 species), which can be classified as Arrhenatheretum elatioris, we investigated the response of the vegetation to the increase of the cutting fre- 
quency from 3 to 5 cuts per year and to nitrogen fertilisation [24]. Attention was focused on the distribution of irradiance within the canopy as a determinant of the growth of white clover which is important for the nutritive value of permanent grassland. The dry matter yields were highest at the first cut, where the leaf area indices, as determined by stratified clipping, varied from 4.7 (03:no N, three cuts) to 6,6 (NN5: $360 \mathrm{~kg} \mathrm{~N} \cdot \mathrm{ha}^{-1}$ and five cuts). Under traditional 03 management, a relatively constant white clover yield proportion of about 5 per cent was found. Five cuts and zero N (05) increased the yield contribution of white clover to 28 per cent. The combination of five cuts and $360 \mathrm{~kg} \mathrm{~N} \cdot \mathrm{ha}^{-1}$ favoured an increase in leaf area density up to $25 \mathrm{~cm}$ above ground. More than 75 per cent of the white clover leaves were found in a PAR (photosynthetically active radiation) transmission zone of below 5 to 9 per cent [31]. The contribution of white clover to the total yield decreased to about 2 per cent. The canopy structure was strongly influenced by the cutting regime and by nitrogen ferti- lisation (figure l). The vertical distribution of the white clover leaf area differed considerably among the treatments. Within the 03 and 05 stands, a large proportion of the white clover foliage was found between 16 and $35 \mathrm{~cm}$ above ground. The leaf area density in the 16 to $35 \mathrm{~cm}$ layer of the NN5 stand was significantly greater than in the two other canopies. Consequently, the amount of incident PAR transmitted to the layers with an appreciable amount of white clover foliage $(<16 \mathrm{~cm})$ decreased to values of only 2 to 3 per cent. The distribution of the relative irradiance indicates that in the 03 and 05 canopies and also for NN5, some of the white clover foliage succeeded in growing up to a position where unintercepted direct or diffuse radiation was transmitted. The leaf area index of white clover was highly correlated $\left(r^{2}=0.68\right)$ with the sunlit fractional area above the canopy layers where white clover was present. Management not only changed canopy structure and relative irradiance, it must also have influenced the light quality.

\section{Relative irradiance}

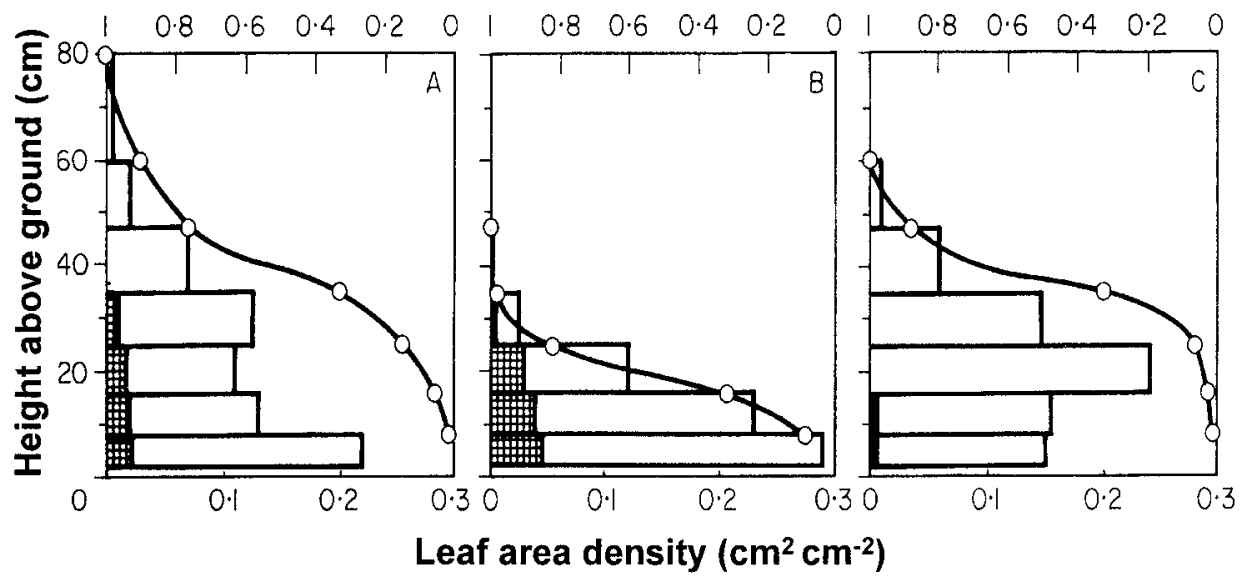

Figure 1. Leaf area density of white clover $(\ldots)$ and remaining vegetation $(\square)$ for $(\mathbf{A})$ three $(03),(\mathbf{B})$ five (05) and (C) five cuts plus $360 \mathrm{~kg} \mathrm{~N} \cdot \mathrm{ha}^{-1}$ per year (NN5) of an Arrhenatheretum elatioris at Chur $(565 \mathrm{~m}$ above sea level). Values are for the first cut $(03)$ on 8 June or the second cut on 28 June $(05)$ and 22 June (NN5) in 1982. The curves represent the relative irradiance ( $/ / \mathrm{I}_{0}$ transmission) of PAR. A. 03 LAI $=5.6$. B. $05 \mathrm{LAI}=4.6$. C. NN5 LAI = 6.6 (according to Schwank et al. $[24]$ ). 
Both reduction in radiation and low red:far-red (R:FR) ratios induce morphogenetic responses in plants such as shade avoidance mechanisms and an increased capacity for capturing light. Furthermore, growth of axillary buds or tillers can be delayed or suppressed under low radiation and R:FR ratios [23]. The light environment of the unfolded leaves of white clover also critically influences its branching behaviour. Compared to the control plants, a reduction in the R:FR ratio reduced the percentage of branched phytomers by 43 per cent on the parent axis and by 75 per cent on primary branches [14]. Furthermore, the number of nodal roots per plant was reduced by about 30 per cent. High plasticity in the extension growth of petioles was an important characteristic that allowed the plant to adapt its height to the height of the shaded area. These different responses to light quality indicate that foraging for light in a vertical rather than a horizontal direction allows white clover to establish itself in dense stands such as in frequently defoliated swards. In infrequently cut swards, petiole growth may not be able to keep pace with the increase in sward height [24], white clover may then be at a disadvantage compared to other legumes such as red clover. However, the growing conditions for white clover are more favourable in extensive grazing systems where the sward structure is very heterogeneous.

\subsection{Meadow fescue: an endangered but important species of permanent grassland in higher and cooler regions}

Grassland in higher and cooler regions is often dominated by large proportions of dicotyledonous species which reduce the quality of the forage and, therefore, animal performance. Lolium species are not adapted to these regions, and most other grasses do not seem to be fairly competitive under such conditions. One possibility is meadow fescue (Festuca pratensis Huds.), which is similar in quality to Lolium sp. and is winter-hardy and productive. However, the competitive ability of meadow fescue seems to be low relative to other species. Meadow fescue is actually present only in small proportions in semi-natural grasslands. More than a hundred years ago the proportion of meadow fescue varied in the lowlands of Switzerland from 9 to 36 per cent in fertilised meadows and pastures at altitudes below $900 \mathrm{~m}$. With the intensification of management, meadow fescue almost disappeared. The reasons for this decline are not known. It was assumed that this decline was the direct response of the species to the intensive management regimes. However, field experiments with monocultures showed that meadow fescue is not negatively affected by frequent cutting and high nitrogen fertilisation [7]. When grown in a binary mixture in the field with a strong competitor (orchard grass), meadow fescue clearly reduced its tilling. The assessment of the importance of the root and shoot competition between both grasses was studied consecutively in a field experiment under fertile soil conditions [3]. The results revealed that the low competitive ability of meadow fescue relative to orchard grass was mainly due to its lower shoot competitive ability. It was assumed that the competitive ability of meadow fescue declined progressively when grown with competitive grasses, probably as a result of an inherently poor capacity for regrowth after defoliation. Our objective was to assess the regrowth of meadow fescue as compared to orchard grass under controlled conditions by the technique of growth analysis. Both species were grown in hydroponics at non-limiting nutrient supply to compare the relative growth rate (RGR) and the dynamics of regrowth immediately after defoliation. The RGR of meadow fescue was lower than that of orchard grass, because dry weight did not increase during the first two days of regrowth. This was caused by a slower increase in the leaf area ratio due to a lower specific leaf area. In addition, the response of above-ground and 
below-ground plant traits to shoot competition and season was compared in a new field study [15]. Therefore, swards of both species were grown as microswards in the field in intraspecific and interspecific shoot competition to assess the effects of season and shoot competition on both species. Meadow fescue was characterised by a higher biomass allocation to the roots and low root activity at soil depths of 0 to $12 \mathrm{~cm}$ and 24 to $36 \mathrm{~cm}$, estimated from the uptake of rubidium and lithium. In contrast, orchard grass allocated more biomass to the stubble, had a higher total water soluble carbohydrate content and root activity. The root competitive ability of meadow fescue was lower compared to orchard grass during summer, but it was similar during spring and autumn for both grasses. This seasonal change in root competitive ability of meadow fescue could affect the seasonal and annual fluctuation of the yield proportion of this grass.

Changes in the distribution of relative leaf area density gave information about the light interception of both species in interspecific shoot competition (figure 2). Averaged over the reproductive growth cycle, the relative leaf area density of meadow fescue was higher in the uppermost canopy layers compared to orchard grass. Therefore, it is assumed that meadow fescue had similar chances in this growth cycle for intercepting radiation as did orchard grass. However, the competitive ability of meadow fescue relative to orchard grass declined progressively after the first regrowth to the end of August. The decline in shoot competitive ability of meadow fescue was a consequence of shading by orchard grass (figure 3) towards the end of regrowth during the vegetative phase. This was due mainly to the shorter leaves of meadow fescue compared to orchard grass and to its generally lower leaf area per plant. The negative effects of the low shoot competitive ability of meadow fescue during summer were not compensated by the benefit of the relatively high competitive ability during reproductive growth and in autumn. The various seasonal effects of root and shoot competition and the changing response of plant attributes during regrowth clearly indicate that the response of pasture plants to shoot competition must be studied during

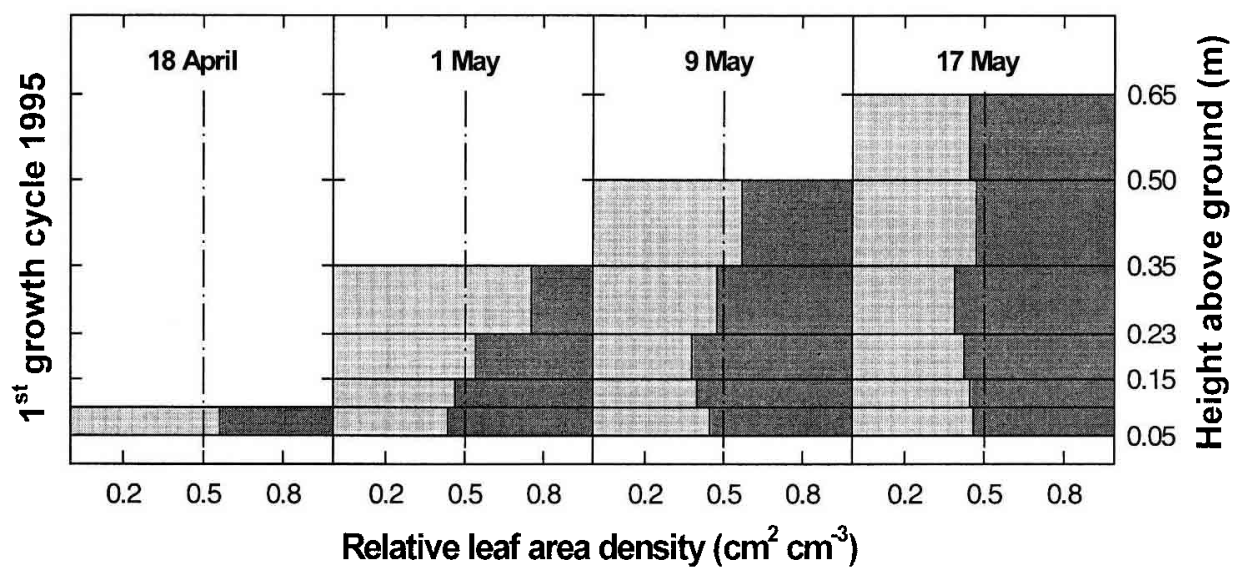

F. pratensis D. glomerata

Figure 2. Changes in the relative leaf area density in different canopy layers in a reproductive sward of meadow fescue and orchard grass grown in the field in interspecific shoot competition during the first growth cycle in 1995. Means of four replicates are shown. 


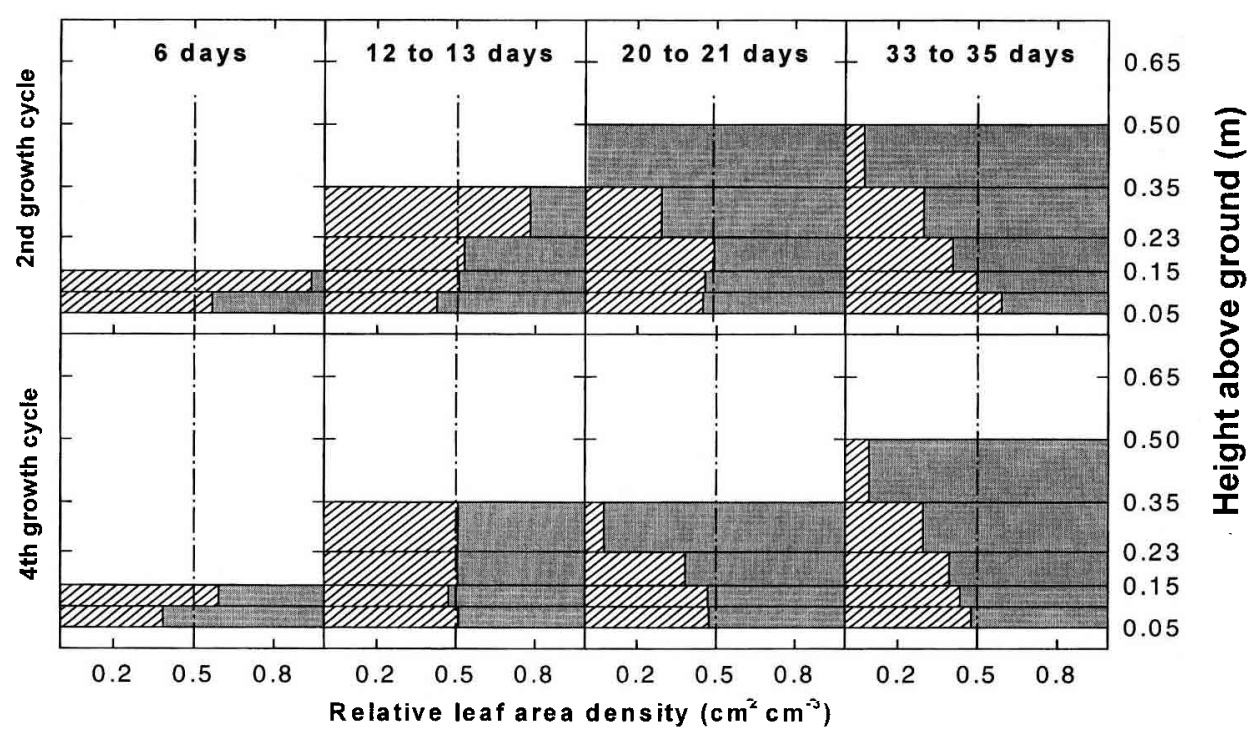

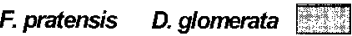

Figure 3. Changes in the relative leaf area density in different canopy layers in a vegetative sward of meadow fescue and orchard grass grown in the field in interspecific shoot competition during the second and fourth growth cycles in 1995. The bars represent the leaf area densities 6,12 to 13,20 to 21 and 33 to 35 days after defoliation on 17 May and 20 July. Means of four replicates are shown.

the entire growing seasons. The analysis of the response of plant traits of meadow fescue and orchard grass to changes in the availability of resources provided insights into the growth strategies of a weak and a strong competitor. The vegetative propagation of both grasses by tilling were related with the changes in their potential to capture light. Therefore, an extensive management system which leads to open and heterogeneous canopy structures creates potential niches where less competitive species can persist.

\section{MANAGEMENT AND MICROEVOLUTION}

Long-term experiments showed that different systems of management changed the abundance of plant species. It seems reasonable to expect that treatments might also act as selective forces on individual species.
Genetic differentiation has been demonstrated in Anthoxanthum odoratum (sweet vernal grass) from the Park Grass plots. Snaydon [26] sampled tillers and collected seeds of Anthoxanthum odoratum in limed and unlimed parts of the plots and grew these in boxes of acidic and calcareous soils. Plants from acidic soils grew better on acidic soil than on calcareous soil, whereas the reverse was true for plants from less acidic plots. Kölliker [12] assessed the genetic variability of meadow fescue in a long-term experiment in the Swiss Alps to determine whether or not fertilisation and defoliation frequency influenced genetic variability within natural populations; he used randomly amplified polymorphic DNA (RAPD) markers and agronomic traits. Analysis of molecular variance showed a significant effect of management on genetic variability. Fertilisation and frequent defoliation led to a reduction in genetic variability [13]. 
The rapidity of such evolutionary changes in response to the management treatments has been surprising. The rapid microevolution probably results from the short generation time of the investigated species and the large selection pressures.

\section{CONCLUSIONS}

Biodiversity is not just one phenomenon but is a concept cluster that involves many facets of biological variety and agricultural land use. A general conclusion is that management for habitat heterogeneity at all scales will conserve most of the biotic diversity of a site. It is impossible to maximise agricultural output and biodiversity simultaneously. Grassland systems which favour biodiversity are multifunctional with conflicting goals. They produce environmental goods and feed for ruminants. Therefore, farmers who manage grassland to improve biodiversity will have to compromise.

\section{REFERENCES}

[I] Bassetti P., Nösberger J., Einfluss der Schnittfrequenz und der Stickstoffdüngung auf die reproduktive Selbstverjüngung von Lolium multiflorum Lam., Das wirtschaftseigene Futter 35 (1990) 265-277.

[2] Burel F., Baudry J., Species diversity in changing agricultural landscapes: A case study in the Pays d'Auge, France, Agricult. Ecosystems Environm. 55 (1995)193-200.

[2] Carlen C., Root competition and shoot competition between Festuca pratensis Huds. and Dactylis glomerata L., PhD thesis No 10512, Eidgenössische Technische Hochschule Zürich, 1994, 106 p.

[4] Daccord R., Valeur nutritive des foins de prairies riches en espèces, Rev. Suisse Agricult. 23 (1991) 36-40.

[5] Grime J.P., Plant Strategies and Vegetation Processes, Wiley, Chichester, 1979.

[6] Grub A., Bungener P., Contat F., Nussbaum S., Endtner V., Fuhrer J., Luftverschmutzung und floristische Biodiversität, Agrarforschung 4 (1997) 332-337.

[7] Gügler B., Die Konkurrenz zwischen Wiesenschwingel (Festuca pratensis Huds.) und Knaulgras (Dactylis glomerata L.) bei verschiedener
Bewirtschaftung. PhD thesis No 10081, Eidgenössische Technische Hochschule Zürich, $1993,81 \mathrm{p}$.

181 Heywood V.H., Baste I., Introduction. in: Heywood V.H. (Ed.), Global Biodiversity Assessment, Cambridge University Press, Cambridge, 1995, pp. 4-19.

[9] Huston M.A., Hidden treatments in ecological experiments: re-evaluating the ecosystem function of biodiversity, Oecologia, 110 (1997) 449-460.

$110]$ Jans F. Les cultures fourragères extensives pour certains animaux, Revue UFA 2 (1995) 35-36.

[11] Kessler W., Lehmann J., Swiss grass-clover mixtures for ley, in: Boller B., Stadelmann F.J. (Eds.), Breeding for a multifunctional agriculture, Swiss Federal Research Station for Agroecology and Agriculture, Zürich-Reckenholz, 1998, pp. 79-82.

[12] Kölliker R., Genetic variability in Festuca pratensis Huds.: effect of management on natural populations and comparison of cultivars to other species, $\mathrm{PhD}$ thesis No 12753, Eidgenössische Technische Hochschule Zürich, 1998, 80 p.

[13] Kölliker R., Stadelmann F.J., Reidy B., Nösberger J., Fertilization and defoliation frequency affect genetic diversity of Fesuca pratensis Huds. in permanent grasslands, Mol. Ecol. (1998); in press.

144 Lötscher M., Nösberger J., Branch and root formation in Trifolium repens is influenced by the light environment of unfolded leaves, Oecologia 111 (1997) 499-504.

[15] Messerli M., Consequences of plant architecture and regrowth capacity for shoot competition among grasses, PhD thesis No 12215 , Eidgenössische Technische Hochschule Zürich, 1997, $192 \mathrm{p}$

[16] Milne J.A., Shelórick R.D., Grassland management and biodiversity, in: Sheldrick R D. (Ed.), Grassland management in environmentally sensitive areas, Occasional Symposium of the British Grassland Society, 32, 1997, pp. 25-32.

[17] Mitchley J., Sward structure with regard to conservation, in: Haggar R.J., Peel S. (Eds.), Grassland management and nature conservation, Occasional Symposium of the British Grassland Society 28, 1994, pp. 43-53.

[18] Nösberger J., The Swiss grassland system, in: Haggar R.J., Peel S. (Eds.), Grassland management and nature conservation, Occasional Symposium of the British Grassland Society, 28 , 1994, pp. 95-103.

[19| Nösberger J., Lehmann J., Jeangros B., Dietl W., Kessler W., Bassetti P., Mitchley J., Grassland production systems and nature conservation, in: Mannetje L., Frame J. (Eds.), Proceedings of the 15th General Meeting of the European Grassland Federation, Wageningen, 1994, pp. 255-265. 
[20] Peters R.H., A critique for ecology. Cambridge University Press, Cambridge, 1991.

[21] Pianka, E., Latitudinal gradients in species diversity: a review of concepts, Am. Nat. 100 (1996), 33-46.

122] Plantureux S., Muller S., Biodiversité, type de sol et intensité de l'exploitation de prairic permantes du Plateau Iorrain, Bot. Gallica I43 (1996) 339-348.

[23] Robin Ch., Hay M.J.M., Newton P.C.D., Effect of light quality (red:far-red ratio) and defoliation treatments applied at a single phytomer on axillary bud outgrowth in Trifolium repens $\mathbf{L}$., Oecologia 100 (1994) 236-242.

[24] Schwank O., Blum H.. Nösberger J., The influence of irradiance distribution on the growth of white clover (Trifolium repens $\mathrm{L}$.) in differently managed canopies of permanent grassland, Ann. Bot. 57 (1986) 273-281.

[25] Silvertown J.W., The dynamics of a grassland ecosystem: botanical equilibrium in the park grass experiment, J. Appl. Ecol. 17 (1980) 491-504.

[26] Snaydon R.W., Rapid population differentiations in a mosaic environment, I. Response of Anthoxanthum odoratum to soils, Evolution 24 (1970) 257-269.

127] Thomet P., Die Pflanzengesellschaften der Schweizer Juraweiden und ihre Beziehung zur Bewirtschaftungsintensität,Tätigkeitsbericht der Naturforschenden Gesellschaft Baselland 31 (1981) 243-367.
[28] Tilman D., Dodd M.E., Silvertown J., Poulton P.R., Johnston A.E., Crawley M.J., The park grass experiment: insights from the most longterm ecological study, in: Leigh R.A., Johnston A.E. (Eds.), Long-term experiments in agricultural and ecological science. CAB International, Wallingford, 1994, pp. 287-303.

[29] Vermeer J.G., Berendse. F., The relationship between nutrient availability, shoot biomass and species-richness in grassland and wetland communities, Vegetatio 53 (1983) 121-126.

[30] West, N.E., Biodiversity on Rangelands: Definitions and Values, in: West N.E. (Ed.), Biodiversity on rangelands, natural resource studies, Vol. IV, Quinney Library, College of Natural Resources, Utah State Univ., Logan, Utah, 1995 , pp. $1-4$.

[31] Winkler L., Nösberger J., Einfluss der Schnitthäufigkeit und N-Düngung auf die Bestandesstruktur und die vertikale Verteilung von Weissklee (Trifolium repens L.) in einer Dauerwiese, J. Agron. Crop Sci. 155 (1985) 43-50.

132] Zimmermann M., Bedeutung der vegetativen und generativen Vermehrung von Festuca pratensis Huds. für seine langfristige Erhaltung in einer Naturwiese. PhD thesis No 11156 , Eidgenössische Technische Hochschule Zürich, $1995,94 \mathrm{p}$.

[33] Zimmermann M., Nösberger J., Effect of management intensities and sward structures on dry matter production of meadow fescue in permanent grassland, J. Agron. Crop Sci. (1998), in press. 